\title{
Learning and Technology Adoption Impacts on Farmer's Productivity
}

Muhammad Sjakir ${ }^{1}$

\author{
Abd Hair Awang ${ }^{2}$ \\ Azima Abdul Manaf ${ }^{3}$ \\ Mohd Yusuf Hussain ${ }^{4}$ \\ Zaimah Ramli5 \\ ${ }^{1} \mathrm{PhD}$ Candidate, Department of Agriculture, Province of South Sulawesi, Indonesia \\ m_sjakir@yahoo.co.id \\ ${ }^{2}$ Associate Professor, Faculty of Social Sciences and Humanities, Universiti Kebangsaan Malaysia \\ hair@ukm.edu.my \\ ${ }^{3}$ Associate Professor, Faculty of Social Sciences and Humanities, Universiti Kebangsaan Malaysia \\ azima@ukm.edu.my \\ ${ }^{4}$ Associate Professor, Faculty of Social Sciences and Humanities, Universiti Kebangsaan Malaysia \\ hmyusoff@ukm.edu.my \\ ${ }^{5}$ Senior Lecturer, Faculty of Social Sciences and Humanities, Universiti Kebangsaan Malaysia \\ zaimahr@ukm.edu.my
}

\section{Doi:10.5901/mjss.2015.v6n4s3p126}

\section{Abstract}

The integrated farmer field school program was implemented to empowered farmers with scientific knowledge, skills, positive attitudes and suitable technology. However, the impact of this program on farmer's productivity has not been comprehensively investigated. Thus, this research examines the farmers' participation in the learning process, technology transfer, adoption of new technology and productivity. This study was conducted in Kabupaten Maros, South Sulawesi, and the total sample size was 168 farmers who have participated in this program. A survey research questionnaire was distributed randomly to the participants from four selected villages after the program. Descriptive and multiple regression analyses were carried out on the data. The results showed that the integrated farmer field school program improved the farmers' knowledge and that extension services were effective in transferring technological expertise. The empirical evidence showed that farmers who participate in the program have significantly increased in paddy productivity. This implies that program is useful to fill gaps in local knowledge with the dissemination and adoption of new agriculture technology. To further improve the farmer field school program, appropriate technological innovations should be identified and issues relating to farm quality and the availability of credits to enable farmers to purchase agricultural equipment and supplies should be addressed.

Keywords: adult learning, technology transfer, farm productivity, farmer field school

\section{Introduction}

The World Bank (2008), estimates that more than 60 percent of rural households in Indonesia engaged in the agricultural sector. The agricultural sector was considered as a major supplier for an industrial raw materials, foods and engine for growth of other economic sectors (Sembiring \& Abdulrahman 2008a; Tahlim \& Wayan 2006). The world needs to produce at least $50 \%$ more food to 9 billion people by 2050 . However, climate change may reduce crop yields by more than $25 \%$ (World Bank, 2015). Annual growth of agriculture sector in Indonesia is only 3.97\% in 2012 compared $4.83 \%$ in 2008 (Pusdatin 2012). In 2009-2010 the contribution of agriculture sector to GDP has declined from $15.3 \%$ to $14 \%$ in 2011 2012 (Ministry of Agriculture 2013a). Employment in the agricultural sector absorb 33.5\% of the total employment and still high (39 million employment) despite the downturn trend (Ministry of Agriculture 2013a; BPS 2012).

The agricultural sector is also become the core to food production, especially rice. Rice has several advantages as a staple food, namely protein, vitamins and high minerals (Kusharto \& Sa'adiah 2006). Therefore, the sustainable agriculture productions play an important role for the national food security stability (Department of Agriculture 2008; World Bank 2015). In 1998, Indonesia became the biggest rice importer (5.959 million tons) in the world (Mashuri 2003) 
and the average import was 744 thousand tons per year in 1983-2011. The shortage of domestic rice supply caused prices surged (Ministry of Agriculture 2013a, World Bank 2015). Indonesia's rice production highly depends on $55.3 \%$ of small-scale farmers (average 0.89 hectare) (BPS 2013). Even, Mubyarto (2002) estimates that almost half of paddy farmers own less than 0.50 hectare.

However Zaini et al. (2009) and Balipta (2010) claims that rice production can be increased by expanding the planting areas and improve productivity. Paddy planting faced many challenges, mainly the availability of agriculture land also decreased due to changes in land use (Entang 2006; Lakollo 2007; Irawan 2003; Siswadi 2009). BPS data (2012) shows that 80 thousand hectares of agricultural land are vanished every year. In addition, the impact coexisting of floods and droughts have reduced food supply (Palmer 2008). Production costs also rose as the price of fertilizers and pesticides are expensive (Adiningsih 2005; Irawan 2011). Even the downturn water supply, water quality, soil fertility, lack of irrigation maintenance and decreasing supply of rural labor (Ministry of Agriculture 2013b; Pasandaran, Sayaka \& Suherman, 2004; Rachman \& Kariyasa 2002; Simatupang 2001). The government has opened a new land starting in 2008 until 2012 with an area of 197,625.3 ha (Ministry of Agriculture 2013b). But the existing rice supply is insufficient and requiring imported rice (Pambudy, Basuki \& Mardianto 2002). The current rice productivity is not increasing rapidly (Pasandaran 2006). For example, in 2009 the rice productivity was 50 tonnes per hectare per year and slightly rises to 51 tonnes per hectare in 2013 (BPS 2013). Hence the agricultural sector should be strengthened accordingly to improve the domestic food supply of and reducing rural poverty (Bappenas, 2010; FAO, 2015a; Harianto 2007; Harniati 2007; Southgate et al. 2001). Rice productivity still can be improved (Adimiharja 2009) such as with optimizing the abilities of farmers and their families, natural resources, technology and socio-cultural environment (Mubyarto 2002; Darajati \& Wahyuningsih 2008: FAO, 2015a). In line with that argument, Soekartawi (1995) concluded that farmers had not mastered the technology, reluctant to adopt new technology, poor in social and economic conditions, and decreasing of soil fertility. The strategy implemented is empowering farmers through field training and technology transfer in integrated farmer field school program. The ultimate goal of the adult learning process, especially among farmers is to free them from the shackles of poverty through improving their cognitive abilities and practical practices as well (FAO, 2015b; Freire 1989, 1994; Chambers 1996; Habermas 1971).

\section{Integrated Farmer Field School}

Integrated farmer field school practice the principles of adult learning (Lunadi 1987) that aims to change the farmer's attitudes and in culturing desired behavior (Braun \& Duveskog 2010; Supriadi, Rusastra \& Ansari 2012; Waddington \& White 2014). The farmer field school was started at Indonesia in the 1980s as an Integrated Pest Management (IPM) program (Mariyono 2007; Braun et. al., 2004; Röling \& Van de Fliert 1994). In 1989 Agriculture Department officials began training for extension workers through collaboration with FAO. In addition, the FAO team and local agricultural extension workers collaborate in investigate the crop pests. USAID also allocated USD 4.7 million to run the Integrated Pest Management (IPM) at the national level for two years to overcome the destructive consequences of nilavarta lugens that destroy 20,000 ha of rice in Java (David 2008). This program is also expected to enhance the ability of farmers to conduct action research, decision-making and sensitivity to the current needs (Ashby et al. 2000; Mariyono 2007, 2009; Schmidt Stiefel \& Hürlimann 1997; Van de Fliert, Pontius \& Röling 1995). In addition, to improve farmers' ability to conduct own research and guide other farmers (Ashby et al., 2000; Braun \& Van de Fliert 1997; Ooi 1996) and stimulate farmers for learning (Braun \& Van de Fliert 1997; Schmidt, Stiefel \& Hürlimann 1997; Settle et al., 1998; Winarto 1995). In Indonesia, a study on farmer field schools generally intended to identify productivity of the crops. The farm productivity can be realized by practicing of technological components obtained during a farmer field school program as experts recommended as mentioned by Bunch (2001) Mariyono (2009) and Soekartawi (2005). Effective guidance and assistance from extension workers needed so that farmers can implement properly new technology (Khalid 2006; Sembiring \& Abdulrachman 2008b; Sumarno et al., 2009; Zaini \& Irsal 2004). The farmer field school approach stress on active engagement of farmers through non-formal learning (Van de Fliert, Pontius \& Roling 1995). According to Asiabaka (2002) and FAO (2001) the active participation of farmers would stimulate learning, transfer and dissemination of agriculture technology to the farmers. Through the learning process the farmers become more efficient in managing their own farm (Khatam et. al., 2010; Khatam, Muhammad \& Ashraf 2013; Van de Fliert \& Braun 2005; Valesco 2000). Therefore the integrated farmer field school is an effective method to accelerate the adoption process of agricultural technologies for productivity enhancement (BPTP 2013; Djoko et al., 2011; Mariyono 2007; Peterson 2015). 


\section{Theoretical Framework}

The relationship between farmers' learning and farm productivity of can be seen from two theoretical approaches. First from economic approached on the human capital theory, particularly by Becker (1962). Farmers considered as an input of the production process. From the training program, farmers are able to increase productivity as acquire knowledge, skills and positive attitude to work (Becker 1962). The second approach, Rogers $(1992,2003)$ stressed that the transfer of technology will enhanced agricultural productivity through the learning process started from the awareness of the needs of knowledge, interest, assess new knowledge, to try and practice the acquired knowledge. The process of transferring knowledge from extension worker to farmers, requires an enabling environment between the receiver and the sender of knowledge, (Nonaka 1994). The effective adult learning principles by Knowles, Holton \& Swanson (1998) focused towards solving daily problems faced by farmers. So the farmer extension program (Van den Ban and Hawkins 1996) was designed to transferring knowledge from researchers to farmers, guide farmers in decision-making, leading farmers to achieve their goals and stimulate the transformation of the agricultural sector. Farmers can learn from their own experience, learn from other people's behavior and improve their own behavior (Mezirow 1981, 1991). Farmers also learn to do something through observation, memorizing and practice (Bandura 1977). The ultimate goal of the adult learning process, especially among farmers is to eradicate poverty through improving the cognitive abilities and worthy practices (Habermas 1971; Freire 1989, 1994; Chambers, 1996).

\section{Research Methodology}

Kabupaten Maros was chosen because it is one of the districts in the Sulawesi, which has implemented integrated farmer field school program since 2008. Rice productivity in the district still less than the average 6 tons/ha (Department of Agriculture Maros 2008) compared to other areas such as Sukabumi 7.8 tons/ha (Sinartani 2009) and Sukamandi is 8.9 tons / ha. This difference gives the impression that the productivity of farmers in this district can be increased (Abdurahman, Maridianto \& Erisal 2007). The population of this research is the farmers attended integrated farmer field school. The population consisted of 290 farmers from four selected villages. The total sample size (n) is calculated using Yamanae (1973) formula. The sample size was stratified for each village on a proportionate basis as shown in Table 1.

Table 1: Sample Size of Integrated Farmer Field School Program

\begin{tabular}{|l|c|c|}
\hline Village/farmer's group & Population & Sample Size $(\mathrm{n})$ \\
\hline Soreang/Sentosa II & 72 & 42 \\
\hline Allepolea/Kayu Sanga II & 97 & 56 \\
\hline Maccini baj/Belang -belang I & 63 & 36 \\
\hline Bontomarannu/Tamalanrea II & 58 & 34 \\
\hline Total & 290 & 168 \\
\hline
\end{tabular}

A survey questionnaire was distributed to the 168 farmers. The farmers were guided to answer the questions and they provided reliable feedback via the survey form. We used the production function model to determined the relationship between production (output) and factors of production (input) captured from previous study (such as Debertin 1986; Doll \& Orazem 1984; Mubyarto 2002; Nicholson 1998; Pindyck \& Rubenfeld 1991, 2001). This study used multiple linear regression analysis to determine the impact of integrated farmer field school on farm productivity $(Y)$. While, the independent variables consist of farmers' participation (X5), effectives communication of the program (X6), competencies of extension worker (X7) and adoption of agriculture technology (X8). The variable age of farmers (X1), farming experience (X2), the level of education of farmers (X3) and land area (X4), as farmer's personnel indicators.

\section{Result}

\subsection{Farmer Profil}

All farmers participating in integrated farmer field school are man. The majority are Bugis (85.1\%), followed by $13.1 \%$ Makassar. Almost all the participants were married (95.2\%) and only $2.4 \%$ are single. Half of the farmers aged less than 49 years and almost half aged 50 to 64 years old. Farmers aged 65 and above are only 1.2\%. According Kartasapoetra (1996), the older farmers difficult to change their ways of thinking, working and life. In term of employment status, $93.4 \%$ 
of them are full-time farmers. Only $6.5 \%$ are part-time farmers. Most (70.8\%) farmers have farming experience 17 to 30 years. The farmer who have the highest experience more than 31 years of farming only $11.3 \%$. The paddy cropping activity is carried out by their family members and become main source of income. A total of $54.2 \%$ of farmers has monthly income between Rp.3 million to Rp6 million a month and $38.1 \%$ of them earning less than monthly Rp3 million. In general, the farmers' income is still at a low level in order to meet basic needs of their family.

Table 2: Farmers' Profil

\begin{tabular}{|c|c|c|c|}
\hline & & Frequency & Percent \\
\hline \multicolumn{4}{|l|}{ Gender } \\
\hline Male & & 168 & 100 \\
\hline Female & & 0 & 0 \\
\hline \multicolumn{4}{|l|}{ Ethnic } \\
\hline Bugis & & 143 & 85.12 \\
\hline Makassar & & 22 & 13.10 \\
\hline Jawa & & 3 & 1.78 \\
\hline \multicolumn{4}{|l|}{ Marital Status } \\
\hline Single & & 4 & 2.38 \\
\hline Married & & 160 & 95.24 \\
\hline Widow & & 4 & 2.38 \\
\hline \multicolumn{4}{|l|}{ Age } \\
\hline Below than 49 years & & 84 & 50.0 \\
\hline 50 to 64 years & & 82 & 48.81 \\
\hline 65 years and above & & 2 & 1.19 \\
\hline \multicolumn{4}{|l|}{ Employment Status } \\
\hline Full-time & & 157 & 93.45 \\
\hline Part-time & & 11 & 6.55 \\
\hline \multicolumn{4}{|l|}{ Farm experience } \\
\hline Less than 16 years & & 30 & 17.86 \\
\hline $17-30$ years & & 119 & 70.83 \\
\hline More than 31 years & & 19 & 11.31 \\
\hline \multicolumn{4}{|c|}{ Farmer's Monthly Income (Rp) } \\
\hline Less than 3 million & & 64 & 38.09 \\
\hline $3-5$ million & & 91 & 54.17 \\
\hline More than 5 million & & 13 & 7.74 \\
\hline \multicolumn{4}{|l|}{ Educational Level } \\
\hline Primary school & (13 years) & 112 & 66.66 \\
\hline Secondary Lower School & (16 years) & 32 & 19.05 \\
\hline Secondary Upper School & (19 years) & 17 & 10.12 \\
\hline Diploma holder & (21 years) & 5 & 2.98 \\
\hline Bachelor Degree & (25 years) & 2 & 1.19 \\
\hline
\end{tabular}

A total of $66.7 \%$ held a elementary school and $19.0 \%$ had lower secondary school qualifications. Only $4.7 \%$ of the farmers had diploma and bachelor degree. Farmers with higher education experience have a tendency to self-study and try new technologies that he believes will increase the farm production (Limbongan, Muh \& Kadir 2011). In terms of land ownership, the overall, $94.0 \%$ of the farmers had irrigated land. Only $21.4 \%$ of the farmers who owned land size between 1.1 hectares up to 2 hectares. The majority (78.6\%). of their land size is less than 1 ha. All farmers use irrigation system for their crops.

\subsection{Famer's Participation in Learning Process}

This section refers to the presence of farmers in the field laboratory. A selected farmers' farm were used as field laboratory for the farmers learning process. The main objective of the learning process is to improve farmers' knowledge based on experience, skills, technology and new information from the integrated farmer field school program. The highest participation of farmers are attending guidance of effective transplanting system (89.9\%), optimum usage of paddy fertilizer (87.5\%) and identification and selection of high yield seeds to suit with the local climate and market (80.4\%). 
However, participation is relative low in land use management (53.6\%), wet seeding technique (60.7\%) and planting technique of high seeds quality (62.5\%). The active engagement of farmers will provide opportunity for the farmers to choose, practice new technology, recommendations to extension workers and researchers, and sharing authentic knowledge with other farmers.

Table 3: Farmers' Participation in Learning Activities

\begin{tabular}{|l|c|c|}
\hline Learning activity & Attended & Not Attended \\
\hline Effective land used management & $53.6 \%$ & $46.4 \%$ \\
\hline Wet seeding technique & $60.7 \%$ & $39.3 \%$ \\
\hline Identification of rice variety for local climate and market & $80.4 \%$ & $19.6 \%$ \\
\hline Selection and planting technique of high quality seeds & $62.5 \%$ & $37.5 \%$ \\
\hline Effective transplanting systems & $89.9 \%$ & $10.1 \%$ \\
\hline Efficient and effective of paddy water management & $73.2 \%$ & $26.8 \%$ \\
\hline Best practices of fertilizer technique & $87.5 \%$ & $12.5 \%$ \\
\hline Creating and usage of organic materials & $70.8 \%$ & $29.2 \%$ \\
\hline Pest and disease control strategy & $79.2 \%$ & $20.8 \%$ \\
\hline Safety and effective pesticide & $72.6 \%$ & $27.4 \%$ \\
\hline Selection of timely harvesting & $89.3 \%$ & $10.7 \%$ \\
\hline Post-harvest management (drying technique) & $77.4 \%$ & $22.6 \%$ \\
\hline Overall attendance & $74.8 \%$ & $25.2 \%$ \\
\hline
\end{tabular}

\subsection{Farmers' Perception}

Extension worker is responsible for explaining the objectives of this program to the farmers. About $50 \%$ of farmers stated that the program objective are clearly communicated, while the others (48.8\%) relatively moderate clear. Only a few farmers $(1.2 \%)$ stated the purpose of this program is not clearly explained by the extension worker. Among the farmers, $58.3 \%$ stated the integrated farmer field school program is appropriate with their daily work routine. Only $28.6 \%$ of the farmers think this program help enhanced their farming technique. Most of the farmers (66.7\%) said the program expanded their paddy cultivation.

Table 4: Farmers Perception of the Program

\begin{tabular}{|l|c|c|c|}
\hline & $1 \& 2$ & 3 & $4 \& 5$ \\
\hline Relevancy of the program & $2(1.2 \%)$ & $82(48.8 \%)$ & $84(50.0 \%)$ \\
\hline Appropriateness of the program & $15(8.9 \%)$ & $98(58.3 \%)$ & $55(32.7 \%)$ \\
\hline Applicability of the program & $8(4.8 \%)$ & $112(66.7 \%)$ & $48(28.6 \%)$ \\
\hline
\end{tabular}

Note: 1 = Strongly Disagree, 2 = Disagree, 3 = Neural, 4 = Agree 5 = Strongly Agree

\subsection{Extension Workers Capabilities}

The farmers believe that extension had a relevant educational background with the subject of integrated farmer field school program. A few farmers (4.8\%) stated is not very relevant. Half of them $(50 \%)$ reported moderate fit, and half (45.2\%) indicated that relevant and highly relevant. This finding showed $62.5 \%$ of the farmers stated that the extension workers are well versed to the subject is sufficient. But the attitude of extension workers in the teaching capability is still at a moderate level (74.4\%). Only $24.4 \%$ said very friendly to the farmers who participate in farmer field school program. Agricultural extension workers are also required to provide appropriate examples with farming activities. Almost $44 \%$ considered moderate and $45.8 \%$ declared that the example shown in accordance with the daily of farmers work life. The extension should be able to stimulate thinking among farmers. Only $10.1 \%$ said no and not very stimulating. While $57.1 \%$ indicated a moderate and $32.7 \%$ stated they stimulate. Overall, extension workers should be efficient and effective but is still at a moderate level. 
Table 5: Capability of the Extension Worker

\begin{tabular}{lccc}
\hline Competencies & $1 \& 2$ & 3 & $4 \& 5$ \\
\hline Educational background relevant to the subject matter. & $8(4.8 \%)$ & $84(50.0 \%)$ & $76(45.2 \%)$ \\
Well-versed of the subject matter & $7(4.2 \%)$ & $56(33.3 \%)$ & $105(62.5 \%)$ \\
Friendly in delivery of the subject matter & $2(1.2 \%)$ & $125(74.4 \%)$ & $41(24.4 \%)$ \\
Demonstrated an applicable examples & $17(10.1 \%)$ & $74(44 \%)$ & $77(45.8 \%)$ \\
Subjects presentation inspire the farmer & $17(10.1 \%)$ & $96(57.1 \%)$ & $55(32.7 \%)$ \\
\hline
\end{tabular}

Note: 1 = Strongly Disagree, 2 = Disagree, 3 = Neural, 4 = Agree 5 = Strongly Agree

\subsection{Adoption of New Technology}

The adoption of technology is not yet sufficiently high, on averaging $69 \%$. Post-harvest techniques learned in the integrated farmer field school program was almost entirely (97 percent) practiced by farmers. Watering gradually technique also was adopted (83.5\%) to prevent water stagnation and appropriate to the of the paddy needs. At the same time to avoid certain microorganisms and animals breeding. Progress irrigation techniques will be nourishing the paddy. In terms of land use management and seeding technique, $77.1 \%$ practice this technique and $73.9 \%$ adopt of a good agriculture practice in utilization of fertilizers and organic materials. However, only $42.0 \%$ practice the plant growth regulator (PGR) or supplementary liquid fertilizer.

Table 6: Adoption of New Technology

\begin{tabular}{lc}
\hline Technological components & Level of adoption (\%) \\
\hline Land used management and seeding technique & 77.08 \\
Seeds selection and planting technique & 60.42 \\
Paddy planting system & 55.74 \\
Utilization of fertilizer and organic resources & 73.69 \\
Irrigation technique & 83.49 \\
Pest and disease control strategy & 61.88 \\
Usage of ZPT/PPC & 42.02 \\
Harvest technique & 97.42 \\
\hline Overall & 68.97 \\
\hline
\end{tabular}

\subsection{Farm Productivity}

Table 7 shows the $t$ test was used to compare the mean productivity of rice before and after the integrated farmer field school program. The results showed there was a difference in productivity of paddy. This program succeeded in increasing the rice productivity to 6.6 tons/ha. Previous research in Indonesia rice productivity from 5.6 tons / ha to 8.5 tons / ha (Sembiring \& Abdulrahman 2008a, 2008b) and farmers obtained 20\% higher than non participant (Zaini \& Erythrina 2008). Arafah et. al., (2002) also noted that technology transfer can improve the rice productivity from 6.5 to 8.3 tons / ha and Wijanyanto (2005) mentioned 7.4 tons / ha. Recent studies, Aidar et al. (2010) found that integrated farmer field school program improved the productivity of rice from an average of 4.7 tons / ha to $6.5-8.3$ tons / ha.

Table 7: Paddy Productivity

\begin{tabular}{ccccc}
\hline Productivity & Mean $(\mathrm{kg})$ & Std Deviation $(\mathrm{Kg})$ & $\mathrm{t}$ & \multicolumn{1}{c}{$\operatorname{Sig}(p)$} \\
\hline Before & $5,314.17$ & $1,979.95$ & \multirow{2}{*}{30.157} & \multirow{2}{*}{$0.00^{* \star}$} \\
\hline After & $6,607.05$ & $2,480.51$ & &
\end{tabular}

\subsection{Determinants of the Paddy Productivity}

The estimating regression equation based on the production function as follows;

$Y=f\left(X_{1}, X_{2}, X_{3}, \ldots, X_{n}\right)$, Where: $Y=$ output and $X_{1}, \ldots, X_{n}=$ production inputs.

$\Delta \mathrm{LN}(Y)=\ln \beta_{0}+\beta_{1} \ln x_{1}+\beta_{2} \ln x_{2}+\beta_{3} \ln x_{3}+\beta_{4} \ln x_{4}+\beta_{5} \ln x_{5}+\beta_{6} \ln x_{6}+\beta_{7} \ln x_{7}+\beta_{8} \ln x_{8}+e$. 
$\triangle Y=$ mean difference of paddy productivity before and after the program.

Table 8 showed that farmer's personal attribute mainly work experience $(B=.530, p<.01)$ has a significant and positive influence on the paddy productivity. However, personal attributes namely farmer's age and the highest level of education are not significant. In terms of the integrated farmer field school indicators, it was found that farmer's participation in the learning process $(\beta=.325, p<.05)$, perception of the program $(\beta=.670, p<.05)$, extension worker capability $(\beta=.403, p<0.05)$ and adoption of new agriculture technology $(\beta=1.01, p<0.5)$ has a positive and significant influence on the paddy productivity. Therefore, the integrated farmer field school program will enhanced the capability of the farmer. Land size $(ß=.275, p<.05)$ was also significant, as shown in Table 8.

Table 8: Determinants of Paddy productivity

\begin{tabular}{|c|c|c|c|c|c|}
\hline Model & $\beta$ & Std.Error & $t$ & Tolerance & VIF \\
\hline (Constant) & -3.377 & 1.967 & -1.717 & & \\
\hline Farmer's age ( $\left.\ln X_{1}\right)$ & -0.182 & 0.252 & -0.723 & 0.413 & 2.422 \\
\hline Farmers experience $\left(\ln X_{2}\right)$ & $0.530^{\star \star \star}$ & 0.125 & 4.251 & 0.440 & 2.272 \\
\hline Farmer's educational qualification $\left(\ln X_{3}\right)$ & 0.048 & 0.080 & 0.596 & 0.671 & 1.490 \\
\hline Land size $\left(\ln X_{4}\right)$ & $0.275^{\star \star}$ & 0.114 & 2.418 & 0.556 & 1.799 \\
\hline Famer's attendance $\left(\ln X_{5}\right)$ & $0.325^{\star \star}$ & 0.179 & 1.816 & 0.699 & 1.430 \\
\hline Farmer's perception $\left(\ln X_{6}\right)$ & $0.670^{\star *}$ & 0.220 & 3.048 & 0.702 & 1.424 \\
\hline Extension worker capability $\left(\ln X_{7}\right)$ & $0.403^{\star *}$ & 0.195 & 2.062 & 0.896 & 1.117 \\
\hline Adoption of new technology $\left(\ln X_{8}\right)$ & $1.008^{\star \star}$ & 0.319 & 3.162 & 0.415 & 2.411 \\
\hline $\mathrm{R}^{2}$ & & & 0.435 & & \\
\hline $\mathrm{F}$ & & & 16.979 & & \\
\hline Sig & & & 0.000 & & \\
\hline df & & & 166 & & \\
\hline $\mathrm{n}$ & & & 168 & & \\
\hline
\end{tabular}

Note: * Significant at $p<0.1,{ }^{* *} p<0.05$ and ${ }^{* \star} p<0.01$.

\section{Discussion and Conclusion}

The integrated farmer field school program managed to spread rice productivity as reported by previous researchers (Arafah et al., 2002; Sembiring \& Abdulrahman 2008a, 2008b; Zaini et al. 2009; Zaini \& Erythrina 2008; Wijayanto 2005). The results of this study also showed a significant effect of work experience as mentioned by prior researchers (Morse \& Buhler 1977; Mosher 1991) because highly experienced farmers often attempt do innovation. Land size also affects the paddy productivity (Azwar 2011: Aidar et al. 2010). However, the active participation of farmers in the field school program showed a high spirit of new things that will benefit the farming industry. David (2008), Ebewore, Egho \& Enujeke (2013), Moumeni-Helali and Ahmadpour (2013), Ortiz et al. (2004), and Osko, Chizari \& Rasoli (2007) states that the active participation of farmers is an important factor in the success of the farmer training program. The farmers are able and willing to apply the knowledge that they understand and develop the new knowledge and skills to plant paddy to obtain better productivity. Similarly, the extension workers capabilities in teaching to disseminate of new technology has significant influence on farm productivity (Hendayana et al. 2009; Hauser et al. (2010). Extension worker can be uplifting farmers motivation and cultivate good faith of latest agriculture technology (Rosganda \& Hendayana 2004; Bulkis 2010). Technological adoption is can be defined as the process of behavior change as knowledge (cognitive), skills and attitudes that are more productive farmers.

\section{References}

Abdurahman, A., Maridianto, S., \& Erisal, J. (2007). "Making farmer as the spearhead of rural incomes". Proceeding of the National Workshop on Dissemination of Agricultural Technology Innovation and Accelerated Development Support, 25-33.

Adimiharja, K. (2009). Farmer: Knitting tradition in the era of globalization, Bandung: Humaniora.

Adiningsih, J. S. (2005). "The role of organic soil in improving the quality and productivity of agricultural land". Workshop and National Congress II Maporina (Organic Agricultural Society Indonesia), Jakarta.

Aidar, R., Amirullah, G.M., Lintong \& Baharuddin, K. (2010). Strategic extension program of the Ministry of Agriculture, Report of BPTP Dissemination, South Sulawesi.

Arafah, S. S., Nasruddin, Fattah, A. \& Syamsiar. (2002). Assessment and development of the irrigated rice intensification based on crop management and resource populations, Institute for Agricultural Technology, South Sulawesi. 
Ashby, J.A., Braun, A.R., Gracia, T., Guerrero, M. P., Hernández, L.A., Quirós, C.A. \& Roa, J. I. (2000). Investing in Farmers as Researchers: Experience with Local Agricultural Research Committees in Latin America. Cali, Colombia: Centro International de Agricultura Tropical.

Asiabaka, C. (2002). "Promotion sustainable extension approaches: Farmer Field School (FFS) and role in sustanaible agriculutural development in African", Internasional Journal of Agrculture and Rural Development, 3, 46-53.

Azwar, S. (2011). "Analysis of socioeconomic factors on the income of rice farmers in the village ciherang Durait River, Kecamatan Babirik", Ziraa'ah 31, 219-225.

Balitpa. (2010). Strategic Plan for Agricultural Research and Development Agency 2010-2014. Jakarta: Badan Litbang Pertanian

Bandura, A. (1977). Social Learning Theory. New Jersey: Prentice Hall.

BAPPENAS. (2010). Evaluation of the revitalizing agriculture in order to improve the welfare of farmers. BAPPENAS, Jakarta.

Becker, G. S. (1962). "Investment in human beings", The Journal of Political Economy,70(5), 9-49.

BPS. (2013). Facts of South Sulawesi South Sulawesi; Indonesia.

BPS. (2012). Employment statistics, Republic of Indonesia. Jakarta.

BPTP. (2013). Instructions and technical assistance of Integrated farmer field school in West Nusa Tenggara. West Nusa Tenggara: BPTP.

Braun, A. \& Duveskog, D. (2010). The farmer field school approach, history global assessment and success stories. Paper project The IFAD, Indonesia.

Braun, A., Jiggins, J., Röling, N., Van den Berg, H., \& Snijders, P. (2004). A Global Survey and Review of Farmer Field School Experiences. Wageningen: International Livestock Research Institute.

Braun, A.R. \& Van de Fliert, E. (1997). "The farmer school approach to IPM and ICM Indonesia user participation", Fith Review and Planning Conference: Institutionalizing Innovations in Root Crop R \&D. Clarck Field. Pampangan. Philippines: Users Perspective with Agricultural Research and Development (UPWARD).

Bulkis. (2010). Program evaluation of rice farmer field school in Bantaeng. Bantaeng: BTPT.

Bunch, R. (2001). Two Corn Cob: On the basis of the agricultural development guidelines. Jakarta : Yayasan Obor Indonesia.

Chambers, R. (1996). Participatory rural appraisal: understanding participatory in rural. Yogyakarta: Yayasan Obor.

Darajati \& Wahyuningsih. (2008). Shaping national food sovereignty. Yogyakarta.

David, J. (2008). "An innovation systems perspective on strengthening agricultural education and training in sub-Saharan Africa", Agricultural Systems, 98,1-9.

Debertin, D. L. (1986). Agricultural Production Economics. USA: Macmillan Publishing Company.

Department of Agriculture Maros. (2008). Annual report of food crops. Kabupaten Maros: Department of Agriculture.

Djoko. ,P., Budi, U., Teguh, P. \& Susanti. (2011). Potential and capability approach rice straw through integrated crop management (ICM) in Central Java. Jakarta: Department of Agriculture.

Doll, J. P., \& Orazem, F. (1984). Production Economics: Theory with Applications. New York: John Wiley \& Sons.

Ebewore, S. O., Egho, E. O., \& Enujeke, E. C. (2013). "Effect of farmer field school training on the management of cocoa marids (Saghbergella singularis) by famers in Edo State Nigeria", Asian Journal of Agricultural Sciences 5, 6-10.

Entang, S. (2006). Land conversion dilemma. Jakarta: Pikiran Rakyat.

FAO. (2001). Farmer innovation and new tecnology options for food production, income generation and combating desertification. Progres Report 2001, FAO.

Food and Agriculture Organization. (2015a). Smallholder and rural poverty. Agricultural Development Economics. http://www.fao. org/economic/esa/esa-activities/esa-smallholders/en/ [26 Mei, 2015].

Food and Agriculture Organization. (2015b). Training and technology transfer. Food Safety and Quality.http://www.fao.org/food/foodsafety-quality/scientific-advice/jemra/technology/ en/ [27 Mei, 2015].

Freire, P. (1989). Education for critical consciousness. New York: Continuum.

Freire, P. (1994). Pedagogy of hope. New York: Continuum.

Habermas, J. (1971). Knowledge and human interest. Boston: Boston Press.

Harianto. (2007). "The role of agriculture in the rural economy". Proceeding of the national seminar on the dynamics of agriculture and rural, Jakarta.

Harniati. (2007). Agricultural oriented program of poverty reduction: Material ingredients of agriculture human resources development, Bogor: Centre for socio economic and policy analysis.

Hauser, M., Aigelsperger, L., Owamani, A., \& Delve, R. J. (2010). "Learning achievements of farmers during the transition to marketoriented organic agriculture in rural Uganda", Journal of Agriculture and Rural Development in The Tropics and Subtropics, 111, 1-11.

Hendayana, S., Erythirina, R.N., Sudamadi \& Widiarta I. N. (2009). Implementation Guidelines for Educational Assistance of integrated farmer field school. Bogor: Department of Agricuture.

Irawan. (2011). Dissemination activities of innovation acceleration research and material organic fertilizer technology. Jakarta: Agency for Agricultural Research and Development.

Irawan. B. (2003). Land conversion in java and its impact on rice production. Jakarta: Agency for Agricultural Research and Development.

Kartasapoetra, A.G. (1996). Agricultural extension technology. Jakarta: PT. Bumi Aksara.

Khalid, A. (2006). Assessing the long-term impact of IPM FFS on farmers' knowledge, attitudes, practices and empowerment: A case 
study from Gezira Scheme, Sudan. http://www.cip-upward.org [1 Julai, 2010].

Khatam, A., Muhammad, S., \& Ashraf, I. (2013). "Role of farmer field schools in enhancing skills of farming community in Khyber Pakhtunkhwa, Pakistan", Pakistan Journal Agriculture Resources, 26, 59-64.

Khatam, A., Muhammad, S., Chaudhry, K.M. \& Mann, A. H. (2010). "Farmers' field schools an alternative strategy to benefit resource poor farmers in NWFP Sarhad", Journal of Agriculture, 26: 689-692.

Knowles, M.S., Holton, E. F., \& Swanson, R. A. (1998). The adult learner. Texas: Gulf Publishing Co.

Kusharto, C. M., \& Sa'adiyah, N. Y. (2006). Evaluation of food consumption, Bogor: IPB Press.

Lakollo (2007). Social dynamics of rural economies: A comparative analysis between the agricultural census, Research report. Bogor: Centre for socio economic and agriculture policy.

Limbongan, J., Muh, T., \& Kadir, S. (2011). Patterns and determinants of adoption of agricultural innovations at specific locations in South Sulawesi, Center for agricultural technology assessment of South Sulawesi.

Lunadi. (1987). Adult education: A practical description for advisers, trainers, coach and extension agents. Jakarta: PT. Gramedia.

Mariyono, J. (2007). "Adoption and diffusion of integrated pest management technology: A case of irrigated rice farm in Jogjakarta Province, Indonesia", Journal of Agricultural Technology, 3, 39-50.

Mariyono, J. (2009). "Integrated pest management training in Indonesia: Does the performance level of farming training matter?", Journal of Rural and Community Development 4, 93-104.

Mashuri. (2003). Financial management in order to raise farmers' progressive agriculture. National workshop working papers, Yogyakarta,

Mezirow, J. (1981). "A critical theory of adult learning and education", Adult Education, 32, 3-24.

Mezirow, J. (1991). Transformative dimension of learning. San Fransisco: Jossey -Bass.

Ministry of Agriculture. (2011). Guidelines for improved production, productivity, and quality of food crops for achieving self-sufficiency and sustainable self-sufficiency in 2011. Jakarta: Ministry of Agriculture.

Ministry of Agriculture. (2013a). Data and information of agriculture. Jakarta: Ministry of Agriculture.

Ministry of Agriculture. (2013b). Expansion and management of prime crop land: Paddy land reclamation in the former sand quarry, Cijambe: Kabupaten Subang.

Morse, S., \& Buhler, W. (1977). "IPM in developing countries: The danger of an ideal", Integrated Pest Management Reviews, 2, 175186.

Mosher, A.T. (1991). Mobilize and agricultural development. Jakarta: Jasigna.

Moumeni-Helali, H., \& Ahmadpour, A. (2013). 'Impact of farmers' field school approach on knowledge, attitude and adoption of rice producers toward biological control: The case of Babol Township, Iran", World Applied Sciences Journal, 21: 862-868.

Mubyarto. (2002). Fundamental of agriculture economics. Jakarta: LP3S.

Nicholson, W. (1998). Microeconomic Theory: Basic Principles and Extensions. USA: Harcourt College Publishers.

Nonaka, I. (1994). "A dynamic theory of organizational knowledge creation", Organization Science, 5 (1), 14-37.

Ooi, P. A. C. (1996). "Experiences in educating rice farmers to understand biological control", Entomophaga, 41, 375-385.

Ortiz, O., Garrett, K. A., Heath, J. J., Orrego, R. \& Nelson, R. J. (2004). "Management of potato blight in the Peruvian highlands: Evaluating the benefits of farmer field schools and farmer participatory research", Plant Disease, 88, 565-571.

Osko, T., Chizari, M. \& Rasoli, S. F. (2007). "Investigation of farmers' field school parcipatory approach effect on knowledge and attitude of rice producers about biological control against Rice Chilo Superssalis", Journal of Iran Agriculture Science, 1-2, 109-119.

Palmer, C. (2008). "Greening agriculture in the developing world", The International Journal for Rural Development.

Pambudy, R. T., Basuki, E. H., \& Mardianto, S. (2002). The rice performance in Asia. Jakarta: Food Security Council Secretariat.

Pasandaran, E.B., Sayaka \& Suherman. (2004). Ecoregional approach in rice production. Jakarta: Agency for agricultural research and development.

Pasandaran. (2006). "Alternative control policy for conversion of irrigated land in Indonesia", Agricultural Research and Development Journal, 25, 1231-1229.

Peterson, W. (2015). The context of extension in agricultural and rural development. Food and Agriculture Organization of the United Nations. Natural Resources Management and Envirenment Department. http://www.fao.org/docrep/w5830e/w5830e05.htm [27 Mei 2015].

Pindyck, R. S., \& Rubenfeld, D. L. (2001). Microeconomics. USA: Prentice Hall International Inc.

Pindyck, R. S., \& Rubinfeld, D. L. (1991). Econometric Models and Economic Forecasts. New York: McGraw-Hill.

Pusdatin. (2012). Macro statistics of agricultural sector. Jakarta: Department of agriculture.

Rachman \& Kariyasa. (2002). Irrigation water management and institutional system in autonomous district. Bogor: Center for research and development of soil and agro-climate.

Rogers, A. (1992). Adults learning for devolepment. London: Cassell Education Ltd.

Rogers, E. M. (2003). Diffusion of innovations. New York: The Free Press.

Röling. N. \& Van de Fliert, E. (1994). "Transforming extension for sustainable agriculture: the case of integrated pest management in Indonesia", Agriculture and Human Values, 11, 96-108.

Rosganda \& Hendayana. (2004). Role and opportunities of commodity IPM-FFS affect cognitive of pepper smallholders.

Schmidt, P., Stiefel, J., \& Hürlimann, M. (1997). Extension of Complex Issues: Success Factors in Integrated Pest Management. Switzerland: Swiss Center for Agricultural Extension.

Sembiring, H. \& Abdulrahman, H. (2008a). Philosophy and dynamics of integrated rice management. Sukamandi: BB rice research. 
Sembiring, H. S. \& Abdulrachman. (2008b). Potential application and development of integrated farmer field school: An effort to increase rice production, IPTEK Tanaman Pangan 3: 145- 155.

Settle, W. H., Whitten, M., Dilts, R. \& Ooi, P. A. C. (1998). "Developments in community IPM for irrigated rice in Asia", Proceeding of the sixth Australasian applied entomological research conference, Australia.

Simatupang, P. (2001). Anatomy of the national rice production problems and efforts to overcome, Proceedings of Agriculture and Forestry 2001 and forward. Jakarta.

Sinartani. (2009). "P2BN in Sukabumi, boost food production", Sinartani, 10.

Siswadi. (2009). "Food self-sufficiency versus land conversion", Harian Umum Pelita, 24 Ogos 2009

Soekartawi. (1995). Farming analysis in Indonesia. Jakarta: UI-Press.

Soekartawi. (2005). Basic principles of agriculture communication. Jakarta: UI-Press.

Southgate, D., Hopkins, J., Gonzales-Vega, C. \& Rodrigez-Meza, J. (2001). Rural poverty, income shocks, and land management: An analysis of the linkage in el Salvador. Project paper AAEA Annual Meeting, Chicago.

Sumarno, U., Kartasasmita, G., Zulkifli, Z. \& Lukman, H. (2009). "Technology adoption gap and paddy production gap", IPTEK Tanaman Pangan, 4, 116- 131.

Supriadi, H., Rusastra, I.W. \& Ansari. (2012). Program policy analysis integrated farmer field school to support national rice production enhancement. Jakarta: Agency for agricultural research and development

Tahlim, S.\& Wayan, R. (2006). Policy strategy of agricultural enterprises in order to increase production and poverty reduction. In, Dariah, A., Neneng, Irawan, Edi, H. \& Agus, F. (Eds). Proceedings of the seminar multifunction and revitalization of agriculture.

The World Bank. (2008). World development report: Agriculture for development. Washington D.C: The world bank.

The World Bank. (2015). Food security overview. Food Security. http://www.worldbank.org/en/topic/foodsecurity/overview. [26 Mei 2015].

Valesco, L. R. (2000). Extension Approaches to rice integrated post management in the Philippines. Proceeding of Workhsop on Recent Agricultural Extension Approaches, University of the Philippines Los Banos.

Van de Fliert, E. \& Braun, T. (2005). Farmer field school for integrated crop management of sweet potato. International Potato Centre, 265.

Van de Fliert, E., Pontius, J., \& Röling, N. (1995). "Searching for strategies to replicate a successful extencion approach: training of IPM trainers in Indonesia", European Journal of Agricultural Education and Extension, 4, 41-63.

Van den Ban, A.W., \& Hawkins, H. S. (1996). Agricultural extension. New York: John Wiley \& Son Inc.

Waddington, H. \& White, H. (2014). Farmer Field Schools from Agricultural Extension to Adult Education. Switzerland: Swiss Centre for Development Cooperation in Technology and Management.

Wijayanto, B. (2005). Phase adoption of crop management and integrated resources in irrigated lowland rice at Central Lampung Regency. Thesis: Universitas Gadjah Mada.

Winarto, Y.T. (1995). "State intervention and farmer creativity integrated pest management among rice farmers in Subang, West Java", Agriculture and Human Values, 12, 47-57.

Yamanae, T. (1973). Statistics: An Introductory Analysis. New York: Haper International.

Zaini, Z. \& Erythrina. (2008). "The expansion of hybrid rice farmer field school approach and rice benchmarking", IPTEK Tanaman Pangan, 3.

Zaini, Z., \& Irsal, L. (2004). Development integrated and resources management options for higher yield and profit in rice farming in Indonesia. Proceeding APEC-ATC Working Group in Training Workshop on Agricultural Technology Transfer and Training, Bandung-Indonesia.

Zaini, Z., Abdurahman, S., Widiarti, N., Wardana, P., Setyorini, D., Kartaatmadja, S. \& Yami. (2009). General guidelines of rice farmer field school. Jakarta: Agency for agricultural research and development. 